This is an electronic reprint of the original article. This reprint may differ from the original in pagination and typographic detail.

Author(s): Laitinen, Kaisa; Valo, Maarit

Title: Meanings of communication technology in virtual team meetings : framing technology-related interaction

Year: $\quad 2018$

Version:

Please cite the original version:

Laitinen, K., \& Valo, M. (2018). Meanings of communication technology in virtual team meetings : framing technology-related interaction. International Journal of Human-Computer Studies, 111, 12-22. https://doi.org/10.1016/j.ijhcs.2017.10.012

All material supplied via JYX is protected by copyright and other intellectual property rights, and duplication or sale of all or part of any of the repository collections is not permitted, except that material may be duplicated by you for your research use or educational purposes in electronic or print form. You must obtain permission for any other use. Electronic or print copies may not be offered, whether for sale or otherwise to anyone who is not an authorised user. 


\title{
Meanings of communication technology in virtual team meetings: Framing technology-related interaction
}

\author{
Kaisa Laitinen $^{\text {a }}$ (Corresponding author) \\ kaisa.a.m.laitinen@jyu.fi \\ Maarit Valo ${ }^{\mathrm{a}}$ \\ maarit.a.valo@jyu.fi \\ ${ }^{a}$ University of Jyvaskyla, Department of Language and Communication Studies. \\ P. O. Box 35, FI-40014 University of Jyvaskyla, Finland
}

\begin{abstract}
Communication technology is an essential part of virtual teams in working life. This article presents a qualitative study on the meanings of communication technology in virtual team meetings. The study was conducted by examining frames of technology-related virtual team interaction. Observational data was gathered from six expert team meetings. Technologyrelated communication episodes $(\mathrm{N}=88)$ were identified from team interaction and then analyzed by means of frame analysis. Four frame categories were found: the practical frame, work frame, user frame, and relational frame. Team members talked about technological properties and functions as well as giving and receiving technological guidance. They also discussed technology in relation to work tasks, contemplated technology users' attributes, and built and maintained relationships with technology. The results indicate that virtual team members give meanings to communication technology while interacting. Communication technology has several meanings - it is seen as a tool for work, a reason for uncertainty, a useful benefit, a challenge, an object of competence, an entity of technical properties, a subject of guidance, a way to express closeness, and a shared space. The results presented in this article deepen our understanding of the role communication technology plays in the dayto-day interaction of virtual teams. The results recommend developing both technological systems and team members' ways of using them, as well as providing opportunities to negotiate the meanings of technology and thus avoid frame disputes. In addition, ensuring that virtual teams use technological systems that support their unique communicational needs is suggested.
\end{abstract}

Keywords: Communication technology, virtual team, team interaction, meaning, frame analysis, frame category 


\section{Introduction}

Virtual teams are common in many modern organizations. They have a unique ability to work across geographic and temporal boundaries throughout organizational structures (Berry, 2011; D’Souza and Colarelli, 2010; Potter and Balthazard, 2002). An increasing number of employees are members of virtual teams, as more than $60 \%$ of multinational organizations use virtual teams and the number will most likely continue to grow in the future (Gilson et al., 2015). According to the definition established by Lipnack and Stamps (2000), virtual teams are relatively small, task-oriented groups of individuals who are, at least to some extent, distributed and mostly work in technology-mediated ways toward a common goal. Virtual team communication is always, to some extent, technology-mediated, and appropriate communication technologies as well as ways to use technology are essential for successful team interaction (Hovde, 2014). However, the effect of communication technology on virtual teams' work and efficacy has been debated for many years, and still some contradictions are apparent in the results (Gilson et al., 2015; Purvanova, 2014).

Previous research seems to agree that communication technology in virtual teams is affected by users' attitudes and perceptions (Purvanova, 2014). Therefore, as communication technology undoubtedly plays a relevant role in virtual team meetings, it is crucial to understand the meanings attached to it. These meanings portray how technology is perceived, valued, and experienced, and thus affect the successful deployment of technology (Davidson, 2006; Fuller et al., 2016). Seeing the sensemaking process of communication technology in work life teams as only rational and pre-given has long since been replaced with more social and interpretive viewpoints. Meanings of technology are affected by the interaction of users as these meanings are expressed and negotiated in their communication (Crider and Ganesh, 2004).

Meanings can be explored with the concepts of frames and framing (Davidson, 2006; Dewulf et al., 2009; Goffman, 1974). Framing research examines how individuals define social reality through frames. Frames can be defined as both structures and schemas in the mind (cognitive frames), and are interpreted and represented in interaction (interactional frames) (Dewulf et al., 2009). Research on technology frames concentrates on the interpretations and definitions of information technology in an organizational context (Bjørn and Ngwenyama, 2010). Orlikowski and Gash (1994, p. 178) have described technological frames as: "the subset of members' organizational frames that concern the assumptions, expectations, and knowledge they use to understand technology in organizations. This 
description includes not only the nature and role of the technology itself, but the specific conditions, applications and consequences of that technology in particular contexts." Technology frames are the knowledge and expectations that guide individuals' interpretations of technology, as well as their actions and interaction with it (Davidson, 2006). In other words, technology has different meanings attached to it by the users, which influences the way they use the technology.

This article contributes theoretically and empirically to these traditions in three ways. First, we apply frame analysis to interaction in team meetings, concentrating on technology frames and framing in team interaction. This kind of application has not been done previously; studies on technology frames have exclusively focused on the organizational level in aiming to understand how users perceive technologies as part of an organization, rather than as part of a virtual team (Bjørn and Ngwenyama, 2010). Second, we use frames and frame category analysis to better understand what meanings are given to communication technology in authentic virtual team communication. Authentic, naturally occurring data allow us to study the realities of virtual teams in real working life and thus better understand how technology should be taken into consideration when studying virtual teams and planning virtual team work. Third, although versatile conferencing platforms are increasingly common in virtual teaming, previous research has not yet focused on them but, rather, mainly on more traditional technologies like email and discussion boards (Gilson et al., 2015). In this article, we focus purely on modern conferencing platforms that are currently used in the everyday working life of virtual teams. First, we will introduce the relevant literature and previous studies on virtual teams and their technology-mediated communication as well as on meanings in team interaction and framing. Then we will move on to describing the methods and data used in this study. Finally, we will introduce the findings and, in the end, discuss these findings, their implications to theory and practice, as well as some future research avenues.

\section{Background}

\subsection{Communication technology in teams}

Research has focused on communication technology in organizations from multiple perspectives. For example, studies have examined the adaptation of technology, attitudes 
toward technology, and technology's role in enabling diverse communication functions (Gilson, 2015). Moreover, a significant number of studies have compared face-to-face communication and computer-mediated communication (Rhoads, 2010). Empirical studies on technology's role in virtual teams have concentrated on technology's effect on team performance (Schweitzer and Duxbury, 2010; Van der Kleij et al., 2009), technology-related attitudes and anxiety (Fuller, Vician, \& Brown, 2016; Luse et al., 2013), technology's role in international teams (Hovde, 2014), technology's effect on ingroup dynamics (Plotnick et al., 2016), and perceptions of technology (Crider and Ganesh, 2004). Nevertheless, research has not yet shed light on the meanings of communication technology that become apparent in actual virtual team meetings.

There are multiple technological systems aimed at fulfilling the communicative needs of teams in working life. Group conferencing platforms, shared workspaces, or online meeting tools are common technology in virtual team use because they provide auditory and/or visual connections between team members (Bouwman et al., 2008; Hovde, 2014). Modern conferencing platforms not only enable multiple, often geographically dispersed, participants to communicate simultaneously, but also facilitate multiple communication functions, such as information sharing, negotiating, problem solving and team decision making. The platforms also usually enable team members to share content, such as text documents, photographs, or web displays.

Group conferencing systems support versatile forms of work and team communication. The effect of technology is, however, not only enabling but sometimes restricting just because of the perceptions of its users. For example, studies have shown that team members with high levels of communication technology anxiety can sometimes participate less, send fewer task-oriented messages, introduce fewer novel topics, and are even rated more poorly by other team members (Fuller et al., 2016). In addition, expectations and previous user experience influence how useful the technology is perceived to be (Treem et al., 2015) and how attitudes toward technology are negotiated during its use (Crider and Ganesh, 2004). Therefore, it is crucial to understand not only the meanings virtual team members assign to communication technology, but also the ways how the meanings are manifested in the team communication.

\subsection{Technology-related meanings and frames}


The constructing and sharing of meanings attached to communication technology have been studied for many years. Twenty five years ago, Fulk (1993) conceptualized how social influence matters in regard to the way individuals perceive communication technology within work life teams. The social influence model was a counter to previous theories that emphasized rational thinking in choosing or using technology (Fulk et al., 1990). Adaptive structuration theory (De Sanctis and Poole, 1994) presented the assumption that social structures fundamentally affect mediated communication. Also coming from the structuration perspective, Weick (1990) described how sensemaking processes are a natural part of using technology, and how these processes are strongly related to the way users utilize and feel toward technology. Weick (1990) defined technology as an equivoque: it can have several possible interpretations. Attitudes toward technology are also frequently regarded as dynamic: team members' attitudes after working by means of communication technology may differ significantly from the attitudes they held before working with the technology (Crider and Ganesh, 2004; Lewis et al., 2005). Technology-related attitudes in the virtual team context have not been a focus of many recent studies. Communication technology anxiety has, however, been found to strongly affect participation in mediated team interaction (Fuller et al., 2016). Research has not yet shed light on the meanings of communication technology in virtual teams. By filling this gap in the research, we aim to be better able to understand how teams deploy technology and ultimately improve their performance. By understanding the meanings, it is possible not only to reveal the prevailing attitudes and perceptions the users have towards technology, but also to enable the active coordination of the meanings inside a virtual team. Coordinated meanings of technology allow for teams to achieve more successful technology-mediated communication, and therefore, they can lead to better collaboration.

Here, meanings attached to communication technology and manifested in team communication are explored through the concept of frames. Framing research is a versatile field of study. Goffman (1974) was one of the first researchers to actively strive toward a clear scientific paradigm of frame (Borah, 2011). However, the concept had already been introduced by Bateson (1972). Goffman (1974) theorized how frames are present in daily interaction, but did not give either clear definitions or methodological tools for observation or analysis (Denzin and Keller, 1981). This aspect of Goffman's work gives researchers a lot of freedom to develop their subjective interpretations and applications of the framing method.

Consequently, the concept of frames has been defined in many ways (Borah, 2011; de Vreese, 2012; Entman, 1993). However, the basic principles are the same: frames refer to the 
unseen structures that define social reality in the minds and interactions of individuals. Frames work as the premises of social situations and to clarify the expectations of communicating in them, thus also affecting the actions of individuals (Goffman, 1974).

Dewulf et al. (2009) differentiated between a cognitive and an interactional paradigm in framing research. This definition highlights frames as both cognitive representations and interactional constructions. The interactional paradigm sees frames as "perspective-based coconstructions of the meaning of the external world" (Dewulf et al., 2009, p. 163). Meanings are constructed in interaction.

In this article, we focus on the interactional paradigm of framing, as we explore meanings attached to communication technology by means of frame analysis. Technology frames have been studied mainly in the context of the organizational level (Bjørn and Ngwenyama, 2010). On the organizational level, four frame categories have been found: frames related to information technology (IT) features or attributes, frames related to potential organizational applications of IT, frames related to incorporating IT into work practices, and frames related to developing IT in organizations (Davidson, 2006). Some work has also been done in the enterprise social media setting, where it has been noticed that employees' frames regarding expectations and assumptions of technology are found to affect their views about the usefulness of social media in their organization (Treem et al., 2015).

It is not, however, yet known what kind of technological frames can be found in the interaction by team members in virtual team meetings. Because of the different contexts in these studies (Davidson, 2006; Orlikowski and Gash, 1994; Treem et al., 2015), it is crucial not to generalize previously found frames but to provide a data-driven analysis of the frames in virtual team contexts. The context of virtual team meetings has not yet been examined from the perspective of frames. More important, the previous framing research has not sufficiently reached into the meanings attached to technology. In addition, there is a lack of virtual team studies that use naturally occurring, authentic team interaction as their data (see Gilson, 2015). This article contributes to these under-developed areas by presenting an analysis of technology frames in virtual teams with naturally occurring data, and by providing a second-level analysis of technology-related meanings.

This literature review led to the following research questions: (1) how is communication technology framed in virtual teams' technology-related interaction? and (2) what meanings are given to communication technology in virtual team meetings? 


\section{Method}

\subsection{Collecting the data}

The data was gathered from three Finnish virtual teams; for every team, two meetings were analyzed. The six meetings were recorded either by the team members themselves (by means of the conferencing platform) or by the researchers (by means of a video camera). All research subjects were aware of the recording of the meetings and had agreed to participate in the study. By using three different teams, we aimed for versatility in the data. All of the teams used conferencing systems that differed slightly from one another. The data was collected from regular meetings of the teams held from 2011 to 2014. With this kind of naturally occurring data, communication is not guided or restricted in any way by the researcher (Silverman, 2006).

Table 1: Studied teams and their attributes.

\begin{tabular}{|c|c|c|c|}
\hline Team attribute & Team 1 & Team 2 & Team 3 \\
\hline Field of work & $\begin{array}{l}\text { Organization consulting } \\
\text { and training }\end{array}$ & Information technology & Information technology \\
\hline $\begin{array}{l}\text { Team members present } \\
\text { at the meetings }\end{array}$ & $2-3$ & $5-13$ & $6-11$ \\
\hline $\begin{array}{l}\text { Level of and reason } \\
\text { for dispersion }\end{array}$ & $\begin{array}{ll}\text { - } & \text { Members } \\
\text { - } & \text { Internalicipating virtually } \\
\text { - } & \text { Distributed } \\
\text { organization } \\
\text { - } & \text { Mobile work } \\
\end{array}$ & $\begin{array}{l}\text { - } \text { Members participating } \\
\text { virtually } \\
\text { - } \text { Internal to Finland } \\
\text { - } \quad \text { Distributed } \\
\text { organization }\end{array}$ & $\begin{array}{l}\text { - } \text { Partially dispersed } \\
\text { team } \\
\text { - Two locations } \\
\text { - Internal to Finland } \\
\text { - } \text { Distributed } \\
\text { organization }\end{array}$ \\
\hline Working nature & $\begin{array}{l}\text { - } \text { Planning projects } \\
\text { - } \text { Planning and } \\
\text { executing materials } \\
\text { - Reflecting past phases } \\
\text { of the project } \\
\text { - } \text { Distributing work }\end{array}$ & 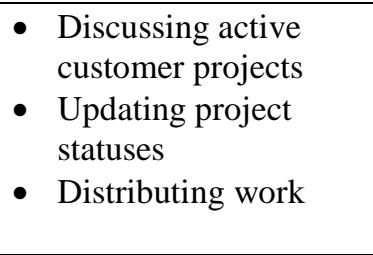 & $\begin{array}{l}\text { Discussing active } \\
\text { customer projects } \\
\text { - Reflecting past phases } \\
\text { of projects } \\
\text { - Showing/demoing } \\
\text { current projects }\end{array}$ \\
\hline Conferencing platform & 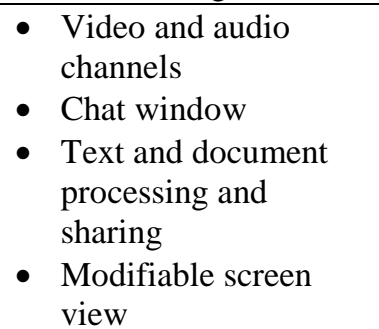 & $\begin{array}{l}\text { - Audio channels and } \\
\text { shared screen view } \\
\text { (operated by the } \\
\text { chair) } \\
\text { - Modifiable screen } \\
\text { view }\end{array}$ & $\begin{array}{l}\text { Audio channels and } \\
\text { shared screen view } \\
\text { (operated by the chair } \\
\text { and the team } \\
\text { members) } \\
\text { Modifiable screen } \\
\text { view }\end{array}$ \\
\hline
\end{tabular}

The first team is from the field of organization consulting. The team uses a versatile webbased video conferencing system that allows the participants to communicate in real time 
through video and audio. The platform enables the advancement of work tasks, such as sharing multimedia documents, processing text documents, and taking notes. The team uses the platform for rather informal, but work-related, meetings. The meetings focus on advancing current team tasks and planning future ones. The team uses the technology to enable cooperation between geographically dispersed team members and also to facilitate mobile work. The team consists of three permanent members who are not all active during the meetings. There are, however, always at least two active members engaged in discussion. The meetings for this team were the longest of all the teams, as the first was 1 hour and 55 minutes and the second was 2 hours and 36 minutes.

The second team works in the field of IT. They use a platform that provides a shared view of a browser screen. The team members participate in the meetings with a mobile phone or computer audio channel. One of the members acts as the chair of the meeting and leads the conversation by following a pre-set agenda. Members who participate through their computers are able to see the shared view and follow the agenda on the browser screen. This team consists of 13 members; however, the number and combination of members participating fluctuates between meetings. The team uses technology-mediated meetings because of the geographically dispersed organizational structure. These meetings are significantly shorter than those of the other teams: the first was 22 minutes and the second was 27 minutes. The short duration could be attributed to the use of a clear agenda and structure that guided the conversation.

The third team is also from IT. Their conferencing system resembles the one used by the second team. This team is partially distributed. Some of the third team's members are physically in the same office space and seated around the same table, while the other part of the team communicates through an audio-based web conferencing system based in another city. In addition to the audio channel, the two parts of the team have access to a shared browser screen, managed by the chair and occasionally by other team members. Depending on the meeting, there are three to six members on each side of the remote connection. The first meeting was 1 hour and 6 minutes and the second meeting was 50 minutes.

\subsection{Conducting the analysis}

The six recorded meetings were transcribed to support the analysis. The analysis was conducted by the first author. However, the authors discussed and evaluated the analysis and negotiated all borderline cases together. This kind of peer debriefing (Lincoln and Guba, 
1985) allows researchers to critically assess their work and thus increase the credibility of their analysis. More generally, the reliability of a qualitative study can be strengthened through sincerity (Tracy, 2010), i.e. transparency of the methodology and analysis. Even though no study is fully free of the researchers' subjectivity, we aimed to manage this challenge by drawing from the theoretical background to confirm our viewpoints. We also provide an exact description of the analysis conducted in this study. Additionally, we include excerpts from the actual data to strengthen the transparency of the analysis.

The analysis had three phases. The first phase was identifying the analysis units, called communication episodes. One episode consisted of one or more statements related to communication technology or the use of technology and, if necessary, the statements pertaining to them. Episodes start either straight from a statement made about communication technology or from a relevant comment that precedes the technology-associated statement. An episode ends when the technology-related statements or other statements relevant to the conversation come to an end. By identifying the communication episodes, we were able to find all of the technology-related conversations from the team meetings.

In total, 88 technology-related communication episodes were identified from all three teams. The first team had 46 episodes, the second team had 25 episodes, and the third team had 17 episodes. The following example illustrates the process of identifying the episodes:

\footnotetext{
[Team members are editing text in their shared view.]

M1 ${ }^{1}$ : What was that one thing [in the text], "about next meetings?" Mikä siellä oli viel se, seuraavista tapaamisista?

M2: "About next meetings" and then "defining project procedures" [M2 writes down]...project procedures...there is still an error [in the text], now it is fine. Seuraavista tapaamisista ja sitte hanketoimenpiteiden. määrittelyä...hanketoimenpiteiden...siellä on vieläkin virhe, joo nyt. - EPISODE BEGINS -

M1: Did you know that if you press Fn and then backspace that it is the same as delete? Tiesitkö et Fn niin sitten peruuta eli backspace on sama kun delete?

M2: No, I didn't [laughs]. En tienny.

- EPISODE ENDS -

M1: And now let's take this end part off. Ja nyt otetaan tää loppuosa tästä pois.

M2: Yes, off. Joo kyllä pois

(Team 1, episode 35)
}

The second phase of the process was the frame analysis of the technology-related interaction found in the previously identified communication episodes. The aim was to form

\footnotetext{
${ }^{1}$ Team members are identified with the numbered letter "M" (for "member"). The number indicates the order in which the team members first appear in that particular meeting. All excerpts presented were translated from Finnish to English by the authors. The original Finnish excerpts are provided next to the translations.
} 
frame categories that describe what team members said about the technology. The frame theory (e.g. Goffman, 1974) provides both the conceptual basis and terminology to support the analysis.

The frame analysis provides descriptions of how individuals understand, define, and construct certain situations, matters, and activities (Goffman 1974). The frame theory does not present any pre-given frame categories - frames are always the result of inductive analyses (Verhoeven, 1993). Moreover, framing has not been previously applied to technology-mediated team interaction. Therefore, the frame analysis of this study was conducted as an inductive, data-driven, qualitative analysis. It was guided by the basic assumptions of frame analysis but not by any previously found frame categories.

All technology-related statements and relevant statements pertaining to them were analyzed on an episode-to-episode basis and then matched and grouped to create the overall frames. Because the communication episodes were formed only to allow the identifying of the technology-related parts of the interaction, multiple kinds of frames could be found in a single communication episode. Frame categories were constructed by analyzing how the technology is talked about by the team members: how the team members define, label, name, describe, and blame the technology by talking about it. These salient (Goffman, 1974) parts of communication are the cues that allow researchers to form a picture of the underlining frames that construct and define the ways the communication technology is perceived in the team interaction.

The following illustration demonstrates the framing process. The relevant observations (e.g., emotional expressions) made from the video or audio material were marked in the transcription. All of the statements were analyzed by looking at the way team members talked about the technology they are using and by finding the salient parts that enabled the framing (see Table 2).

Table 2: Example of defining the frames.

(Team 2, episode 16)

M2: (Name1) is now online.

The member is organizing the technical connection and describing actions done with technology. Practical frame

M1: This doesn't allow to put two names (in the 


\begin{tabular}{|c|c|}
\hline $\begin{array}{l}\text { work distribution system) Well, I'll write here M1 } \\
\text { and M2. }\end{array}$ & Practical frame, Work frame \\
\hline [A team member's phone is put on hold.] & \\
\hline $\begin{array}{l}\text { M2: Who is on hold now? } \\
\text { M3: M3 was on hold! }\end{array}$ & $\begin{array}{l}\text { The member is organizing the connection, but } \\
\text { doesn't know who is on hold. } \rightarrow \text { Technology's } \\
\text { restriction/properties. } \\
\text { Practical frame }\end{array}$ \\
\hline $\begin{array}{l}\text { M1: Ah okay, welcome back. } \\
\text { M3: Thanks! [laughs] }\end{array}$ & $\begin{array}{l}\text { Technology described as something you can go } \\
\text { away from and come back to. } \\
\text { Practical frame }\end{array}$ \\
\hline $\begin{array}{l}\text { M1: Then another (program) has spawned a gig, } \\
\text { so there is need for new measures for (program). } \\
\text { This has been discussed previously so I just put } \\
\text { these names in - - and then there was the update }\end{array}$ & $\begin{array}{l}\text { The member is defining technology as an object of } \\
\text { work tasks. Organizing future work tasks and } \\
\text { distributing work. } \\
\text { Work frame }\end{array}$ \\
\hline $\begin{array}{l}\text { of the third (program)'s manual. Can M5 say } \\
\text { something about this? }\end{array}$ & \\
\hline $\begin{array}{l}\text { M5: Well, I wrote down today that (name2) } \\
\text { mentioned that it is probably going to them but I } \\
\text { don't have (name2)'s confirmation about it. }\end{array}$ & $\begin{array}{l}\text { Advancing work tasks and distributing work with } \\
\text { technology. } \\
\text { Work frame }\end{array}$ \\
\hline $\begin{array}{l}\text { M1: Okay, well is (name2) online? No, (name2) is } \\
\text { not online... }\end{array}$ & $\begin{array}{l}\text { The member is organizing the connection and } \\
\text { describing actions done with technology. Doesn't } \\
\text { know who are present } \rightarrow \text { Technology's } \\
\text { restriction/properties. } \\
\text { Practical frame }\end{array}$ \\
\hline
\end{tabular}

The third phase of the analysis was the interpretation of the meanings. Frames are conceptualizations of reality, both in individuals' minds and through social constructions that emerge in communication. Frames consist of the meanings that are given to subjects, relationships, practices, and structures (Goffman, 1974). Frames are entities of meanings. Meanings, then, are more specific constructs. The meaning of an object - here: communication technology - is interpreted in its frame. For example, seeing technology in a game frame would yield quite a different interpretation of the meaning 'technology as a challenge', as compared to a work frame. There are both cognitive meanings assigned by individuals (and thus guiding their actions) and joint meanings negotiated socially in communication.

In this study, meanings were inductively derived from the previously constructed frame categories. Because frames are entities of meanings, the analysis was not necessarily linear. The deriving of meanings was executed by inductively and constantly recognizing, through 
the lens of the frames, such verbal and nonverbal expressions, that carried a meaning attached to the technology the teams used. These verbal and nonverbal expressions were cues for recognizing the meanings team members had for the technology. Some examples of these cues are introduced in the section 4.2. The interpretation of meanings is the second level of our two-level analysis. We highlight the impact of the meanings by executing this secondlevel analysis and thus making them a visible part of the findings.

\section{Findings}

\subsection{Frames of technology-related interaction}

The technology-related interaction of the virtual teams takes place in four different frames: practical frame, work frame, user frame, and relational frame (see Table 3).

Table 3: The frames of technology-related interaction and the number of episodes in which they take place in virtual team meetings.

\begin{tabular}{|ccccc|}
\hline Frames & Team 1 & Team 2 & Team 3 & Total \\
\hline Practical frame & 32 & 15 & 15 & 62 \\
\hline Work frame & 15 & 16 & - & 40 \\
\hline User frame & 8 & 1 & - & 5 \\
\hline Relational frame & 5 & - & & 5 \\
\hline
\end{tabular}

\subsubsection{Practical frame}

The technology-related interaction was, in most instances, framed in the practical frame (see Table 3). In the practical frame, the team interaction focused mainly on two topics: discussing technology's properties and functions, and providing guidance on the use of the technology.

First, technology was seen by the participants as an entity of technological properties and as a platform for team members' communication. The frame was manifested in the interaction when the team members described and explained their actions with the 
technology, stated and solved technology-related problems, shared opinions about and experiences with the technology, and organized technical connections with one another.

Excerpt 1 illustrates how communication technology is defined through its features. In the excerpt, the team members are trying to solve a technology-related connection issue.

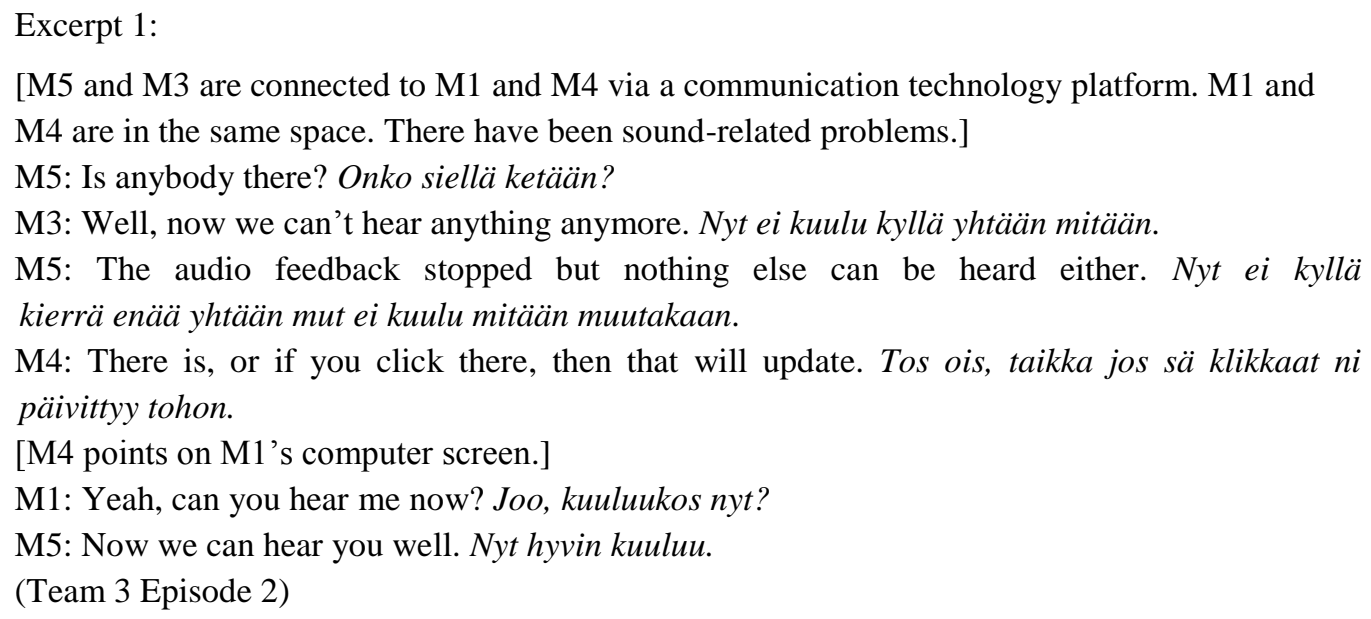

The restrictions caused by communication technology's properties were described by team members. Technology was, for example, labeled as "not allowing" some form of action, as can be seen in the following excerpt.

\footnotetext{
Excerpt 2: skippaamaan tästä pois.

M3: Okay. Joo.

M1: I will be back soon. Mä tuun kohta takas.

[M1 leaves the team conversation.]

(Team 1 Episode 35)
}

M1: Hey, it seems that I can't enter two rooms simultaneously... I have to skip myself out from here. Hei tää on näköjään, muuten ei pääse kahteen huoneeseen yhtä aikaa...mä joudun

Technology was not discussed only in a neutral way but also evaluated in team members' statements. In excerpt 3, team members talk about technology as being convenient and working very well and in this way, they define the possibilities of the platform. Team members also represent the technology by characterizing their previous experiences or, in this case, lack of experience.

\section{Excerpt 3:}

M3: This is also a new type of working if we both do our own stuff, and still we are in this space... This is fun [laughs]. I also have never seen anything like this. Tääkin on ihan uudenlaista työskentelyä jos me tavallaan tehään kumpikin tässä omia ja sit me ollaan täs tilassa, tää on hauskaa [nauraa], en mäkään tämmöstä koskaan. 
M1: But isn't it convenient, because if we have to talk about something, then well... Mutta eikös tää oo kätevää ku jos meijän tarttee jutella jostain niin tota.

M3: Yeah, this is incredibly convenient. This works very well. Joo on ihan älyttömän kätevää tää toimii tosi hyvin.

M1: Yes. Joo.

(Team 1 Episode 29)

Second, there were also multiple statements in which the team members asked, gave, and received guidance on the use of the technology and its properties. These statements included both neutral guidance on technology use and evaluative statements regarding technology's properties.

In excerpt 4, a team member expresses distress quite strongly. These emotionally loaded statements are targeted to saving a document on a platform. One team member defines technology in terms of difficulties. Another member, however, guides the distressed member in using the platform. The one giving guidance to the other describes the platform in a more neutral series of actions and features, and thus does not evaluate the technology so strongly.

\footnotetext{
Excerpt 4:

M3: Eek, oh no, eek, oh no, well, how is it put here then? Iik ääk iiik ääk no miten se nyt sitte tänne.

M2: Go to the "records," then there is that "modify" button. Mee pöytäkirjaan, siihen tulee se muokkaa-painike.

M3: Modify, yeah, that is true. Muokkaa joo totta.

M2: And then paste it there. Ja sit sitte sinne liitä.

M3: True, true, and now then paste... allow use? Totta totta ja nyt sitte liitä... salli käyttö?

M2: Allow use, yes. Salli käyttö kyllä.

M3: There, and save. Noin tallenna.

M2: Mm-m.

M3: Is it there now, is everything now done? Onks se nyt siellä onks nyt kaikki tehty? M2: I will go and check, yes very good, it is there. Mä meen kattoon, erittäin hyvä se on siellä.

M3: And now I can close this system without a concern? Ja nytkö sitten voi tän laittaa huoletta kiinni tän tän systeemin?

M2: Yes. Kyllä.

(Team 1 Episode 24)
}

Sometimes the technology was also perceived in terms of the possibilities it provides for the team. In excerpt 5 , one member gives instruction, or a tip, to the others and describes communication technology as a handy tool enabling the members to adopt new practices. 


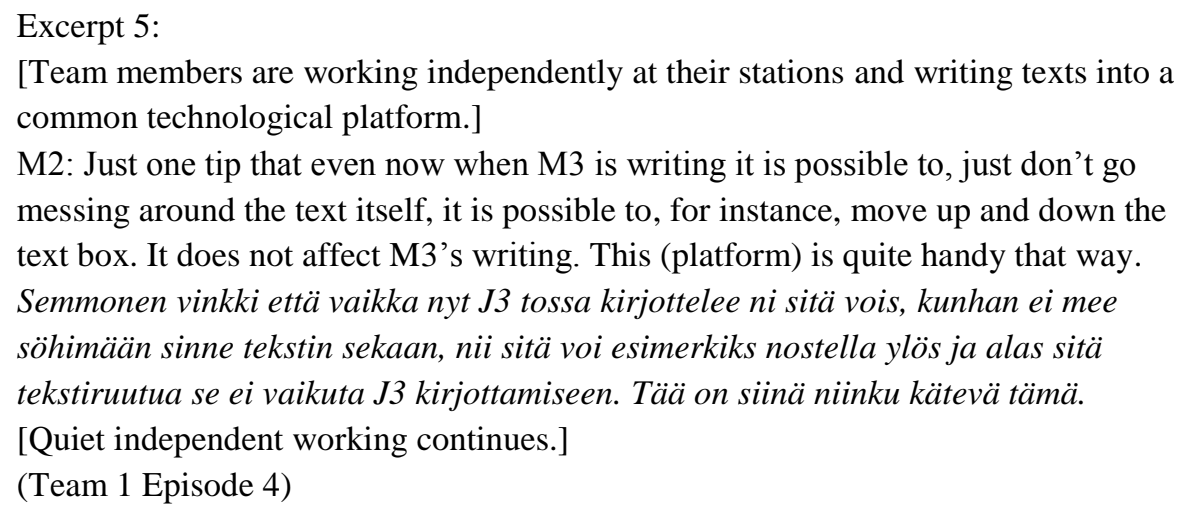

In the practical frame, the communication technology was, first of all, seen as an entity of technological properties and defined by the team members by describing their actions with the technology, solving technology-related problems, sharing opinions about and experiences with the technology, as well as organizing technical connections. Second, the team members also asked, gave, and received guidance on the use of the technology and its properties. These statements included both neutral guidance on technology use and evaluative statements regarding technology's properties.

\subsubsection{Work frame}

The work frame consisted of technology-related statements connected to the teams' work tasks. Every one of the studied virtual team meetings was work-related by default, so it is clear that the teams performed multiple task-related processes and aimed to achieve workrelated goals. Depending on the team's characteristics and the nature of the meeting, the work tasks varied from the informal planning of future projects to well-structured reviewing of the tasks that had already been performed and those that needed to be performed in the future. Team members advanced their tasks, for example, by describing the next phase for the task or using technology to distribute work. In the work frame, the communication technology was often seen as a tool that could be used to advance the team's work-related goals.

In excerpt 6, the technology is mentioned in relation to the work task at hand. The technology is seen an object that facilitates some of the team members' work.

\section{Excerpt 6:}

M3: About that, I did write those dates down somewhere. Ja tota siihen liittyen sitten mä laitoin ne kyl jonnekin ylöskin niitä päivämääriä.

M2: You can see your email there. Tossa näkyy se sun meili. 
[Email message is visible in one of the conferencing platform's text boxes.]

M1: So, fifth of June [workgroup name] meeting. Viides kuudetta [ryhmän nimi]

kokous.

M3: Yes, yeah so on fifth of June is [name of the meeting] [--] we could, for example,

settle that in [name of a platform] so that we write down in bullet points our

observations of this phase of the project. Joo, joo eli viides kuudetta on [kokouksen

nimi] [--] me voitas vaikka sopia [alustan nimi] niin että laitetaan vaan ihan

ranskalaisilla viivoilla meijän havaintoja hankkeen tästä vaiheesta.

(Team 1 Episode 20)

In their meetings, the virtual teams often made decisions related to the distribution of work. Here (excerpt 7), the technology is portrayed as an object for some members to do their work with. Technology is categorized as a tool for work distribution needs.

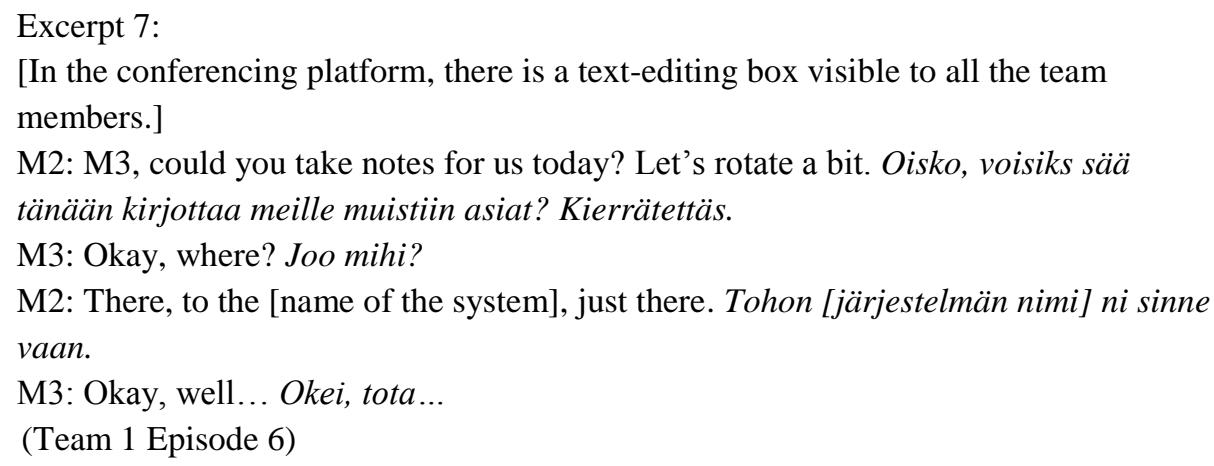

In the work frame, the technology was seen as a platform for the teams to perform multiple task-related processes and achieve work-related goals. The team members advanced their tasks by describing the next phases of the project and by using technology for distributing their work.

\subsubsection{User frame}

The user frame manifests in the team meetings when the members share thoughts about the relationship between technology and its users. The interaction about technology users' attributes manifested in two ways. First, team member conversations considered both the attributes of the team members and technology users in general. These attributes are, for example, habits, practices, or traits. Second, team members also had conversations about the issues relating to technical competence.

In the user frame, the technology was portrayed, both visually and verbally, as a reflection of its users. In excerpt 8, technology is even given gender-related attributes. 


\section{Excerpt 8:}

[M3 and M1 are both female and M2 is male.]

M3: What are you, why are you smiling, M2? [laughs] While M3 talks, you smile the whole time. Mitäs sää mitä J2 sä hymyilet? [nauraa] ku J1 puhuu nii sä hymyilet koko ajan.

M2: Well, you don't follow my chat messaging at all, you are just focused on that auditory communication. [M2 has asked for a bathroom break in the chat window.] Ku te ette seuraa mun chattiviestintää ollenkaan et työ vaan keskityitte tohon auditiiviseen kommunikointiin

M1: What? [laughs] Mitä?

M3: Ooohhahha [laughs].

M1: He is squirming, look, with legs crossed, can you see, okay, pee break. Se kiemurtelee kato jalat ristissä huomaattekste okei pissatauko.

M3: Well, I noticed your facial expressions, hello, I do observe. No mut mä huomasin sun ilmeen hei haloo mä havainnoin kyllä.

M1: He has his legs crossed, can you see he has crossed legs. Sillä on jalat ristissä, näätsä sillä on jalat ristissä.

M3: But hey, here is this kind of, listen M2, here is the difference between men and women, that women follow expressions. Mut hei tässä on tämmönen, täs on J2 miesnaisero, et nainen seuraa ilmeitä.

M1: Yes and men read text [laughs]. Kyllä ja mies katselee tekstiä.

M3: Yes and focus on the computer, yeah, that's right. Niin ja keskittyy koneeseen, nii just.

M2: Yes. Kyllä.

(Team 1 Episode 10)

In excerpt 9, one team member reflects his feelings of uncertainty in using the conferencing platform. Technology is defined as "untrustworthy" and as an object of suspicion.

\section{Excerpt 9:}

[M3 has done an entry about the team's meeting to a virtual proceedings system.] M3: Well, now you should go and check if it went there because I am very suspicious of these things. Tota nyt saatte käydä vielä kattomassa sen et meniks se sinne, koska mä oon hirveen epäluulonen näissä asioissa.

M1: It is here. Tuli.

M2: It went there okay, I can see it, I'm in here. Meni meni okei mä nään sen, mä oon sisällä.

M3: I can never believe that it truly goes there. Mä mä en koskaan usko sitä et se menee sinne.

M1: It is here, it is here. Tuli tuli.

(Team 1 Episode 24) 
In the user frame, technology is seen through the relationship between technology and its users. The team members discuss the attributes of technology users and issues related to technical competence.

\subsubsection{Relational frame}

In the relational frame, the conversation about communication technology is focused on the relationships between team members. In the relational frame, the interaction has multiple characteristics, such as expressing humor and showing emotions both verbally and nonverbally using the visual dimension of the platform. In this frame, the team does not primarily advance any work task in its interaction. The technology does not manifest itself as a tool to work with, but instead as a platform to build, maintain, and develop relationships. Technology is used to express informality and closeness by even giving virtual "hugs" (see excerpt 10). The relational frame appeared only in the conversations of one team-it did not exist in either of the other two teams.

Excerpt 10:

M1: Now, if you were here, I would hug you, but I can instead give you this kind of, like, remote hug. [M1 tries to place their hands in a way it looks like M1 is hugging the video screen.] Nyt jos te oisitte tässä niin mä halaisin teitä mut mä voin antaa teille nyt tämmösen niinku kaukohalauksen. [levittää käsiään kohti videokameraa ikään kuin halatessa].

M2: Big hug [opens up his arms simulating hugging]. Iso hali [levittää käsiään videoruudussa kuin halatessa].

M1: I will give you a remote hug, remote hug. Annan teille kaukohalauksen, kaukohalaus.

M3: Oh, it is done like that? Ai se tehään noin?

M1: Like this [shows again]. Näin [näyttää uudelleen].

M3: Now I will try to put these hands here, now here you can see that you M2 can do that, but I cannot get these here in front of the camera, well, now I succeeded quite well.

Ny mä yritän mä yritän laittaa nää kädet tänne nyt tossa sen näkee J2 et sää pystyt tekee ton mut mä en saa näitä tähän kameran eteen, no nyt onnistu aika hyvin. M2: It is great. On hieno.

M3: Look how big my hands are [laughs]. Kattokaa miten isot kädet mulla on [nauraa].

M2: Good. Hyvä.

M3: M1 is still swaying there, it is not focusing, not focusing. J1 vielä heiluu tuolla, et ei kohdistu, ei kohdistu.

M1: No, no... look, is it better now? Ei ei ... kato onks nyt parempi?

M3: Well, now, now you got it, good! No nyt nyt nyt onnistu, hyvä!

(Team 1 Episode 22) 
Technology was defined as a system that positively affects team members' relationships and strengthens their team performance (see excerpt 11).

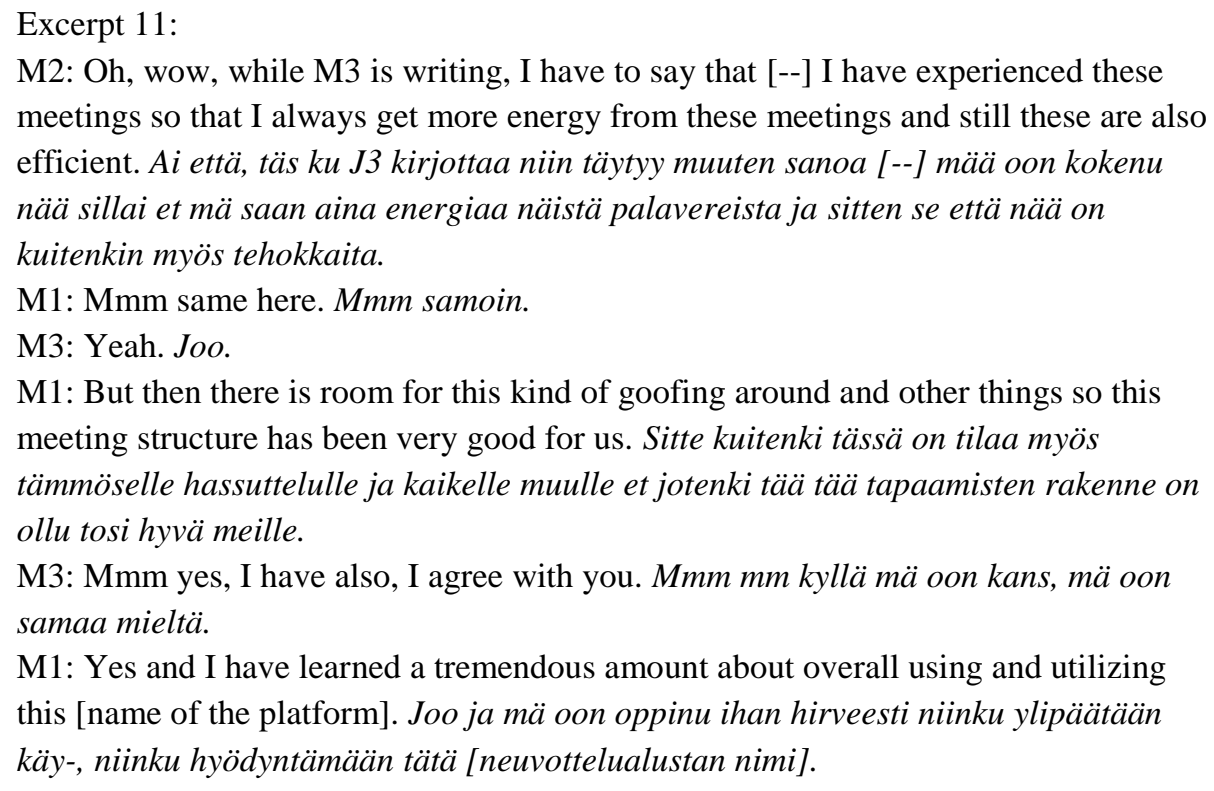

(Team 1 Episode 21)

In the relational frame, the team interaction was focused on the relationships between team members. The team does not necessarily advance any work task in its interaction, but instead the technology is used to express informality and closeness.

\subsection{Meanings of communication technology}

The frame categories presented in the previous section provide us with an interpretation of technology-related meanings. In total, nine meanings were inductively interpreted during the third phase of the analysis to be present in the frames (see Table 4).

Table 4: Meanings of communication technology found in the frame categories.

\begin{tabular}{|c|c|}
\hline Frames & Meanings of communication technology \\
\hline Practical frame & $\begin{array}{ll}\text { - } & \text { entity of technological properties } \\
\text { - } & \text { challenge } \\
\text { - } & \text { subject of guidance }\end{array}$ \\
\hline
\end{tabular}




\begin{tabular}{|ll|}
\hline Work frame & $\bullet$ tool \\
& $\bullet$ useful benefit \\
\hline User frame & $\bullet$ object of competence \\
& reason for uncertainty \\
\hline Relational frame & $\bullet$ way to express affection \\
& $\bullet$ \\
\hline
\end{tabular}

The communication technology utilized in the team meetings had nine meanings: an entity of technological properties, a challenge, a subject of guidance, a tool, a useful benefit, an object of competence, a reason for uncertainty, a way to express affection, and a shared space.

In the practical frame, the technological platform is meaningful for the team as an entity of technical properties. Virtual team members talk about the properties and functions of the platform both in their current work and in their future tasks and processes. Technology is not only talked about, but also utilized in different ways in diverse parts of the meetings. Technology is also given the meaning of being a challenge. This meaning was mostly expressed because of the technical difficulties team members faced. For example, when the connection does not work, there is evident uncertainty that is voiced by inquiring: "Is [member] present?" or "Can you hear me?" The technical guidance given to other team members is quite elaborate and detailed, for example: "Did you know that if you press Ctrl and F you can search for things?" Therefore, in the practical frame, the communication technology has the meaning of possessing properties to ask about, and give and receive guidance on. For example, statements like "Press 'save' in the upper corner" and "Where is that button?" are indications of guidance-related meaning. Technology is not only a neutral entity of properties and functions, but also evaluated by the users. These evaluations portray the underlying attitudes which shape the use of the technology.

In the work frame, the communication technology is meaningful for the virtual teams as a tool-it makes task-related communication possible and allows work to advance. Through the technology, the teams can achieve goals that would not be possible for a distributed team without it. Virtual teams both utilize technology to plan the progress of projects and intend to use communication technology again in the future phases of the projects. For example, the statement "We could plan this [project] in the [system]" shows team members making plans to utilize communication technology in a future work task and thus assigning it the meaning 
of a tool. The technological platform is also a way to make the work visible by allowing team members to present the progress achieved in the work tasks, for example: "I'll show here [at the shared view] what I have done." The platform is used as a tool to take notes and keep a record of the current meeting. The communication technology is also meaningful for the team members as a benefit that yields many possibilities for their work. Platforms do not only enable team meetings, but also a number of other specific functions, such as sharing documents and web screens. Communication technology is described as, for example, "handy" and "working very well."

In the user frame, the interaction around the communication technology is closely connected to the concepts of competence and skills. Statements like "People like me usually find this difficult" or "I adore your ability to use these things so naturally" highlight how technology is defined to be an object of competence. The team members discuss and compare the abilities of different users in relation to each other. For example, the team members are said to have "asymmetry" in their competence with technology and in their ways of utilizing the platform. Technical skills are also compared to other types of competences, such as conversation skills and playing the piano. The platform is not only present as a neutral entity of technical properties but also as a target of evaluative and even critical comments. Technology means uncertainty. It is given meanings based on the team members' previous experiences. There is uncertainty regarding technological functions, and difficulty trusting the technology, especially in one of the teams. Technology is defined as untrustworthy, for example, by the following statements: "I am always so suspicious about these" or "I can never believe that it [text document] truly goes there [web portal]."

In the relational frame, the technology is discussed in terms of team relationships and is valued as a possibility for good teamwork and relationship building. The interaction in the relational frame shows that the teams perceive the technology as a means of expressing affection. Therefore, conferencing platforms are perceived as bringing individuals closer to one another, even though this is not physically possible. Communication technology even allows the team members to give virtual hugs and express closeness in the common virtual space. The interaction in the relational frame also illustrates how technology means a shared space for the teams. The conferencing platform is a common denominator and a way to connect with one another. Often the technology is referred to by using the word "this," while the speaker assumes that the other team member knows what "this" is. The team members also stated how they should "stay here around the table," even though there really was no physical table to stay around. One team member can also give directions such as "write in 
here" or "choose from there" and the others will understand the meaning because of the shared view of their virtual workspace. Even though the teams were distributed, the members regarded the technology as a shared space.

\section{Discussion}

In this article, we explored the meanings attached to communication technology in authentic virtual team interaction by using the frame category analysis. We were aiming to find answers to two overall research questions: (1) how is communication technology framed in virtual teams' technology-related interaction? and (2) what meanings are given to communication technology in virtual team meetings?

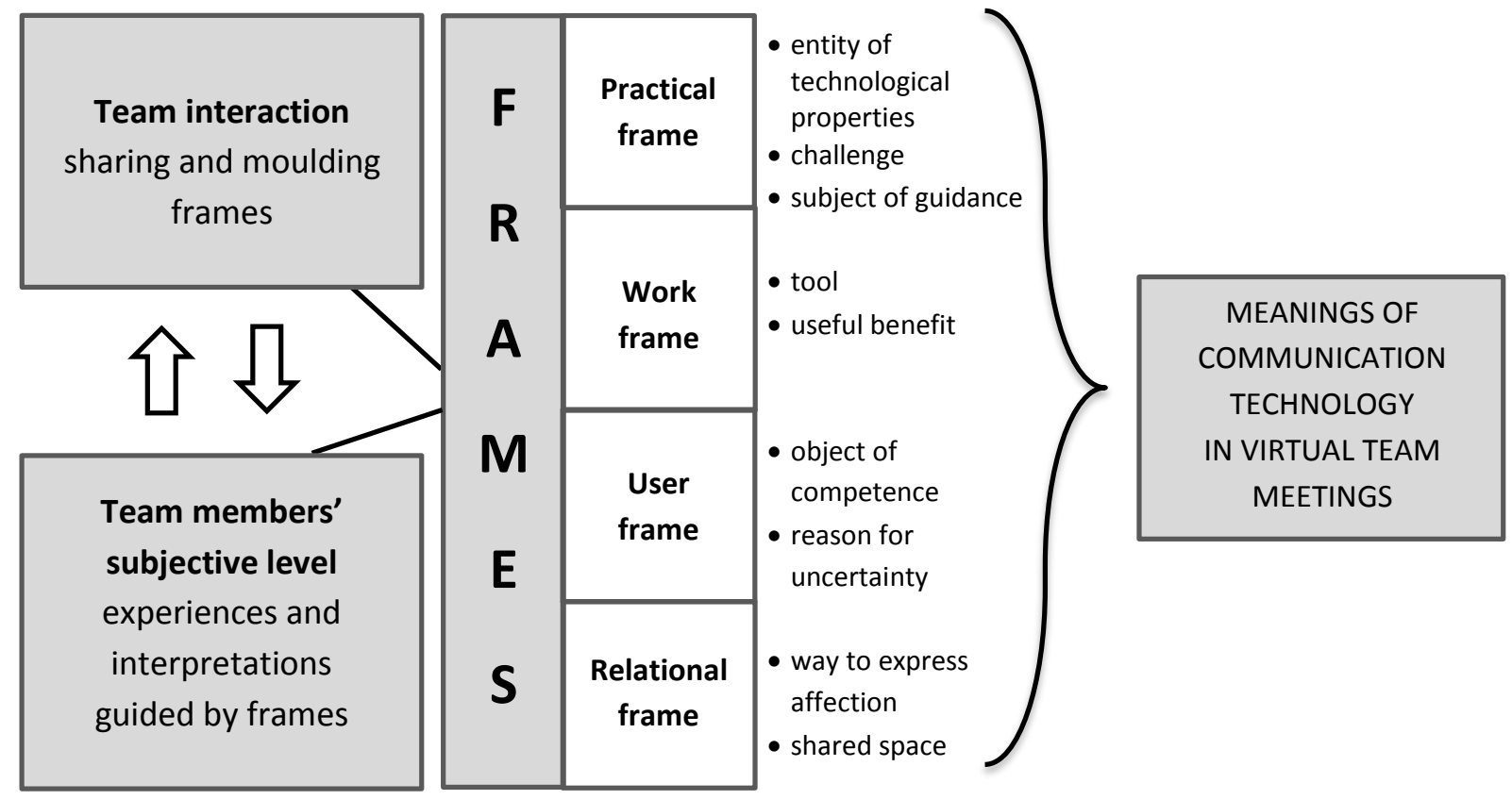

Fig. 1: Frames in virtual teams' technology-related interaction and the meanings attached to communication technology.

We found that there are four frames that define virtual teams' technology-related interaction: practical frame, work frame, user frame, and relational frame (see Fig. 1). Team members comment on the technology's properties, provide guidance on the use of technology, negotiate the technology users' attributes, and maintain and develop relationships by using the technology. By framing the technology-related conversation in teams, we were able to outline what communication technology means for them. 
Nine technology-related meanings were interpreted on the basis of the frames. The technological platform was portrayed as an entity of technical properties, a challenge to manage, and a subject of guidance. It was meaningful as a tool and a useful benefit with many possibilities. Technology was seen as an object of competence and a reason for uncertainty. It was a way to express affection, even by simulating physical contact. Also, technology meant shared space between the team members.

The practical frame and the meanings attached to it demonstrate how technology and its properties are managed in hands-on moments during team interaction. The discussions about technological issues emerging in meetings indicate that the applied technology as such-as an entity of technological properties - is extremely meaningful for its users: the team platform has to function, and fulfil the purposes, tasks and processes of teamwork. Technological issues bring out emergent negotiations of the meanings of technology in teams, especially when the users are confronted with technical challenges. Even though some amount of practical framing is definitely an essential part of team discussions, there might be less of it if the technology worked well and its properties and possibilities were clear to all users.

The work frame provides meanings of team technology that are strongly related to the context of its use. Technology means both a tool and a useful benefit without which the teams could not have their meetings. Because the technology is used for teamwork, the meanings are attached to the communication tasks at hand. The teaming platforms used by the team members are, for a large part, truly implemented for the work purposes and used for achieving work goals.

The user frame allows seeing communication technology as a reflection of its individual users. The technology used in teams has both positive and negative connotations. Team members see themselves and the other members as more or less competent users of technology. The teaming platforms, with a great number of properties and potentials, can also be regarded as a source of uncertainty. The technology was defined even as untrustworthy, which, in some cases, lead to avoiding the use of technology altogether. The members' previous experiences with technology are clearly shown in team discussions.

The relational frame portrays communication technology as a means of building, maintaining and reinforcing team relationships. The technology allows the team members to have their mediated meetings with face-to-face elements, such as auditory and visual connections between the members. Communication technology is, therefore, neither just an entity of technical properties nor a tool for completing work tasks. It is also a space for 
relational interaction and a means to show interpersonal affection. Technology is a way for teams to experience and express togetherness in a shared space while being physically dispersed.

All the frames indicate that the ways team technology is perceived, valued, and experienced can affect the successful deployment of technology. Conferencing platforms used by virtual teams have personal-level meanings, and the technology is a crucial part of the team and its work. Below, we discuss the findings and their implications. We also discuss the limitations of the study, and present future research possibilities.

\subsection{Differences between the teams and technologies}

The three teams were in many ways similar, but they also had their differences. The versatility of the teams is reflected in the results. In the first team, all of the frames were present, but in the other two teams, only the first three frames-the practical frame, work frame, and user frame-were found. It was, however, expected that the frames could differ from team to team.

The first team was more focused on the members and their relationships, and the uncertainty regarding the platform was much more present. The reason for this degree of uncertainty might be found when the structure, style, and content of the meetings of the three teams are compared. In the second and third team, the meetings were clearly focused on work-related matters (e.g., planning the project's progress and distributing work), whereas in the first team, these tasks were accompanied by changing thoughts and ideas, as well as catching up with each other's personal lives. In addition, the team culture of the first team seemed to allow a more informal and emotionally loaded interaction than the culture of the other teams.

The conferencing platforms used in the teams were, likewise, different and they enabled diverse functions. The first team had a real-time video connection, which allowed them to see each other. The second team communicated mainly by audio and a shared web screen. The third team was partially distributed: one part of the team was in the same meeting room and others were connected through an audio channel. The user frame and relational frame and the meanings of competence and affection attached to them were most present in the first team. Their presence might have been prompted by the meeting style, structure, or the properties of the technology. The user frame portrayed a team culture that allowed for talk about team members' own attributes and experiences that also did not necessarily relate to 
work. However, in the relational frame, the video connection was essential, as the team members used it even to the extent of giving "hugs."

The differences in the teams are not surprising in and of themselves. Every virtual team is a unique group comprised of individuals and their relationships. Because one crucial part of choosing the technology is that it should fill the unique needs of individual teams, it is clear that different teams do and should use different technologies (Hovde, 2014). Our results seem to confirm that technology does have unique meanings on different teams and that the technology itself also shapes the work and interaction in the team, thus technologies need to be suited to the individual team's needs.

\subsection{Theoretical implications}

This study provides theoretical and empirical contributions to the frame theory and to the research field of virtual teams. The frames found in our study share some similarities with the technology frames used in the studies of technological frames of reference (Davidson, 2006). These four categories are frames related to information technology (IT) features or attributes, frames related to the potential organizational applications of IT, frames related to incorporating IT into work practices, and frames related to developing IT in organizations (Davidson, 2006). According to our study, in virtual teams, technology is similarly framed with regard to its features and its usefulness in the context of teamwork. What differentiates IT framing at the organizational executive level and the framing of communication technology in virtual teams are the two other frame categories we found. The appearance of relational and user frames indicates that in the virtual team context, technology also has relationship-, competence-, and user-related meanings attached to it. Therefore, conferencing platforms in virtual teams seem to have more personal-level meanings, and the technology is meaningful mainly as a part of the team and its work. Future research of technology frames should pay attention to the possibility of frames that are related to individual users and their interpersonal relationships.

The communication technology utilized in the virtual teams is given the meanings of being an entity of properties and a tool for advancing work tasks. Our findings indicate that conferencing platforms are, as expected, a crucial part of virtual teams. Previous research does not fully concur on what effect technology and technologically mediated communication has on the virtual team's performance or if it has any effect at all (Gilson et al., 2015). According to our findings, it is apparent that in addition to the actual use of the technology, the interaction about the technology is also a part of the virtual team meetings' 
reality. This insight needs to be taken into account when discussing connections between technology use and efficacy in virtual teams.

Our findings indicate that virtual team interaction includes solving technical difficulties and assigning negative meanings to technology's properties and functions. Many of these meanings were related to technical problems; for instance, when the Internet connection was not working the way it should. Communication technology was not, however, given only negative meanings. First, the expressions of uncertainty regarding the technology and technological competence appeared only in one of the three studied teams. Second, the teams also gave the communication technology a vast number of positive meanings, as they described it as convenient and a useful tool to achieve work-related tasks. The technology also has meanings related to its users and its possibilities of expressing presence and affection when the team members are not physically present in the same space.

Therefore, the benefits of communication technology are such a valuable part of virtual team communication that technology cannot be seen only as a difficulty. Crider and Ganesh (2004) have previously studied how virtual teams negotiate meanings in their communication. According to their study, when team members are expressing difficulties or challenges associated with technology, the other team members tend to express social support and empathy. Technology-related problems are seen as a way for team members to build relationships and become closer. These findings were supported by our study.

\subsection{Practical implications}

Studying the meanings of technology for virtual teams allows us to understand how communication technology in working life is perceived and valued. These perceptions can affect the successful deployment of the technology. If technology-related meanings are understood, it is possible to address the negative meanings, such as uncertainty, and aim to advance the properties that are positively meaningful in relation to the team and their work.

Our findings indicate that these team members give the technology meaning as an object of competence. Team members giving and receiving guidance on technical troubles makes it apparent, on one hand, that it is possible to provide guidance on the platforms' use. However, on the other hand, the practice of giving and receiving guidance also indicates that the team members can experience a lack of competence. Experiencing lack of competence can arouse meanings of uncertainty towards technology. This situation can even lead to avoiding tasks that involve communication through technology. However, we found that members of virtual teams ask, give and receive guidance on technical issues from one another. This means that 
they perceive technical skills worth developing. The results of our research verify the finding from previous research (Berry, 2011) that virtual team members benefit from versatile competence, or at least from an experience of sufficient competence. To advance efficient working practices, it is essential to focus not only on developing the communication technologies, but also to recognize and, if needed, develop the technological competence of team members.

Our findings can also be practically utilized by communication consultants working with technology-mediated teams. The manifestation of the practical, work, user and relational framing indicate that technology is viewed as a crucial part of group processes. Virtual team members should be as conscious as possible about the meanings they attach to communication technology. They should also be aware of other team members' perceptions. It is therefore recommended that virtual team members discuss communication technology before and during its use. The joint processing of various approaches to teaming technology would prevent frame disputes (Goffman, 1974) or contradictory meanings. Mixed understanding about the use of technology can lead to the team not using the technology as effectively as they potentially could. For example, a person who strongly perceives technology in the relational frame may not work well with a member who is more influenced by the practical frame. Also, because frames can include expectations of roles and behavior (Goffman, 1974), frame disputes could lead to a mixed understanding about roles and expected behavior within the virtual team.

To conclude, the results of our study can be applied to planning virtual team communication processes and practices. To manage the challenges of virtual communication and to facilitate more efficient work practices, it is essential to focus not only on developing communication technologies, but also on recognizing the experiences and competences of the users. It needs to be ensured that the meeting practices and structures are appropriate. In addition, it is necessary to make sure that virtual teams use technology that is especially suited to their communication needs and thus has the right properties and functions, as well as to provide the possibility for the team members to discuss their attitudes and perceptions related to technology.

\subsection{Insights from this study, limitations, and future research}

Even though there have already been a substantial number of virtual team studies conducted, many of them focused on more traditional platforms, such as email, chat, and discussion boards, where communication is mainly text-based (Gilson et al, 2015). Our study focuses on 
modern conferencing platforms that are currently used by virtual teams. Moreover, our theoretical and methodological background in frame analysis provides a novel viewpoint that has not been previously applied to virtual teams. Our data consisted of six meetings from three virtual teams. We aimed for versatility in the data, and the three teams provided a good variety of working-life virtual teams. Even though the data were derived from only three teams, the differences and similarities between the teams provided novel insights on virtual team meanings - more than a case study of one team would have offered. The data were large enough to fit the purpose of our study; however, further studies on larger volumes of virtual team data could be conducted to affirm our findings or to add other dimensions.

A qualitative study should have resonance by offering, at least to some extent, transferable findings (Tracy, 2010). It is also possible to study the meanings assigned to technology by student teams and achieve insightful results. However, by observing naturally occurring conversations in team meetings in real working life, we were able to obtain novel insights on the actual meanings prevailing in the workplace today. Therefore, some presumptions on other similar working-life teams can be made. Our results indicate that technology-related meanings within virtual teams include perceptions and values that are related to technology's properties and work practices. Virtual teams using a modern conferencing platform can also have meanings related to relationships and competence, but these meanings do not necessarily manifest in all meetings or in every team.

Future studies should further examine if the technology-related meanings are shared and held as collective beliefs among the team members or if they are more likely just individual perceptions. The distinction between meanings representing a collective belief of the team or individuals' own perceptions can be examined by analyzing the level of team cohesion. In the groups with a high level of attraction, the individual members tend to more easily absorb the attitudes and meanings prevailing in the group communication (Fulk, 1993). By analyzing how widely the shared meanings are held, it would be possible to discover if individual members' perceptions and the team's collective entity of meanings have inconsistencies. This kind of research could also contribute to the discussion about contradictory meanings and frame disputes, and provide both empirical findings and practical implications about their significance to the field of virtual teamwork.

Another path for future research would be to continue studying the meanings that virtual team members assign to their technology-mediated communication competence. Our study indicates that a perceived lack of technical skills can transform into uncertainty regarding communication technology use. It is necessary to further study how perceived competence 
affects the formation of positive and negative meanings attached to communication technology.

Future research should continue to observe virtual team members as communication technology users. For example, to what extent are the practices to use communication technology shared within a team? Observing the possible changes of meanings over time could offer more insights on the development of teams. It would be worthwhile to examine if the meanings stay similar or if they change while the team itself changes dynamically over time. Studies should also be conducted in the context of multinational teams and teams using different kinds of technologies to examine cultural and technological effects.

\section{Acknowledgments}

The data used in this article were collected in the 'Interpersonal Communication Competence in Virtual Teams' research project, funded by the Academy of Finland (Department of Communication, University of Jyvaskyla).

\section{References}

Bateson, G., 1972. Steps Toward an Ecology of Mind. Ballantine, New York.

Berry G.R., 2011. Enhancing effectiveness on virtual teams: Understanding why traditional team skills are insufficient. Journal of Business Communication 48, 186-206.

Bjørn, P., Ngwenyama, O., 2010. Technology alignment: A new area in virtual team research. IEEE Transactions on Professional Communication 53, 382-400.

Borah, P., 2011. Conceptual issues in framing theory: A systematic examination of a decade's literature. Journal of Communication 61, 246-263.

Bouwman, H., Van Den Hooff, B., Van De Wijngaert, L., Van Dijk, J., 2008. Information and Communication Technology in Organizations. Reprint, Sage, London.

Crider, J.A., Ganesh, S., 2004. Negotiating meaning in virtual teams: Context, roles and computer mediated communication in college classrooms, in: Godar, S.H., Ferris, S.P. (Eds.), Virtual and Collaborative Teams: Process, Technologies and Practice. Idea Group, Hershey, pp. 133-155.

Davidson, E., 2006. A technological frames perspective on information technology and organizational change. Journal of Applied Behavioral Science 42, 23-39.

Denzin, N., Keller, C., 1981. Frame analysis reconsidered. Contemporary Sociology 10, 
$52-60$.

De Sanctis, G., Poole, M.S., 1994. Capturing the complexity in advanced technology use:

Adaptive structuration theory. Organization Science 5, 121-147.

de Vreese, C., 2012. New avenues for framing research. American Behavioral Scientist 56, $365-375$.

Dewulf, A., Gray, B., Putnam, L., Lewicki, R., Aarts, N., Bouwen, R., van Woerkum, C., 2009. Disentangling approaches to framing in conflict and negotiation research: A meta-paradigmatic perspective. Human Relations 62, 155-193.

D’Souza, G.C., Colarelli, S.M., 2010. Team member selection decisions for virtual versus face-to-face teams. Computers in Human Behavior 26, 630-635.

Entman, R.B., 1993. Framing: Toward clarification of a fractured paradigm. Journal of Communication 43, 51-58.

Fulk, J., 1993. Social construction of communication technology. The Academy of Management Journal 36, 921-950.

Fulk, J., Schmitz, J., Steinfield, C.W., 1990. A social influence model of technology use, in: Fulk, J., Steinfield, C. (Eds.), Organizations and Communication Technology. Sage, Thousand Oaks, pp. 117-140.

Fuller, R. M., Vician, C. M., Brown, S. A., 2016. Longitudinal effects of computer-mediated communication anxiety on interaction in virtual teams. IEEE Transactions on Professional Communication 59, 166-185

Gilson, L.L., Maynard, M.T., Young, N.C., Vartiainen, M., Hakonen, M., 2015. Virtual teams research: 10 years, 10 themes and 10 opportunities. Journal of Management 41, 1313-1337.

Goffman, E., 1974. Frame analysis: An Essay on the Organization of Experience, Harper, New York.

Hovde, M. R., 2014. Factors that enable and challenge international engineering communication: A case study of a United States/British design team. IEEE Transactions on Professional Communication 57, 242-265.

Lewis, D., Shea, T., Daley, T. M., 2005. The effect of virtual team membership on attitudes towards technology usage: A study of student attitudes in the United States. International Journal of Management, 22, 3-10.

Lincoln, Y.S., Guba, E.G., 1985. Naturalistic Inquiry. Sage, Thousand Oaks.

Lipnack, J., Stamps, J., 2000. Virtual Teams: People Working across Boundaries with Technology, second ed. John Wiley \& Sons, New York. 
Luse, A., Mennecke, B., Triplett, J., 2013. The changing nature of user attitudes toward virtual world technology: A longitudinal study. Computers in Human Behavior 29, 1122-1132.

Orlikowski, W J., Gash, D. C., 1994. Technological frames: Making sense of information technology in organizations. ACM Transactions on Information Systems 12, 174-207.

Plotnick, L., Hiltz, S. R., Privman, R., 2016. Ingroup dynamics and perceived effectiveness of partially distributed teams. IEEE Transactions on Professional Communication 59, 203-229.

Potter, R.E., Balthazard, P.A., 2002. Virtual team interaction styles: Assessment and effects. International Journal of Human-Computer Studies 56, 423-443.

Purvanova, R. K., 2014. Face-to-face versus virtual teams: What have we really learned? The Psychologist-Manager Journal 17, 2-29.

Rhoads, M., 2010. Face-to-face and computer-mediated communication: What does theory tell us and what have we learned so far? Journal of Planning Literature 25, $111-122$.

Schweitzer, L., Duxbury, L., 2010. Conceptualizing and measuring the virtuality of teams. Information Systems Journal 20, 267-295.

Silverman, D., 2006. Interpreting qualitative data. 3rd edition, Sage, Thousand Oaks.

Tracy, S. J., 2010. Qualitative quality: Eight "big-tent” criteria for excellent qualitative research. Qualitative Inquiry 16, 837-851.

Treem, J. W., Dailey, S. L., Pierce, C. S, Leonardi, P. M., 2015. Bringing technological frames to work: How previous experience with social media shapes the technology's meaning in an organization. Journal of Communication 65, $396-422$.

Van der Kleij, R., Schraagen, J.M., Werkhoven, P., De Dreu, C.K., 2009. How conversations change over time in face-to-face and video-mediated communication. Small Group Research 40, 355-381.

Verhoeven, J., 1993. An interview with Erving Goffman, 1980. Research on Language and Social Interaction 26, 317-348.

Weick, K., 1990. Technology as equivoque: Sensemaking in new technologies, in: Goodman, P.S., Sproull, L.S. \& Associates. (Eds.), Technology and Organizations. Jossey-Bass, San Francisco, pp. 1-44. 